\title{
THE STUDY INTO FACTORS REDUCING INVESTMENT PROJECT FINANCING RISKS
}

\section{Umar S.-E. KHAKHANAEV}

Chechen State University (CHSU), Grozny, Chechen Republic, Russian Federation

desperade@mail.ru

https://orcid.org/0000-0003-1616-2920

\section{Article history:}

Article No. 558/2019

Received 13 August 2019

Received in revised form

27 August 2019

Accepted 10 September 2019

Available online

25 December 2019

JEL classification: G31, G32

Keywords: investment project, financing, risk, cash flow, risk reduction

\begin{abstract}
Subject The article discusses the issue of revitalizing factors that reduce risks of investment project financing through a new risk classification set forth specifically for investment projects.

Objectives The article represents an empirical study into a new task of investment project financing, that is the identification of the most cost-effective financial sources and generation of cash flows as much as possible. This task requires to build a model for the gradual creation of a risk catalog, classify types of risks, describe risk factors and their impact on an investment process, determine what should be done to find factors reducing
\end{abstract} the risk of investment project financing.

Methods The study relies upon the Net Present Value (NPV) method, index-based method, comparative analysis, time series analysis.

Results The article presents the outcome of a comprehensive analysis of factors reducing the risk of investment project financing. I propose my own classification of risks identified by group of factors and describe them. The article formulates methodological recommendations to manage risks of investment project financing in an innovative manner and use the relevant tools, i.e. the catalog of factors reducing investment project financing risks.

Conclusions and Relevance There should be the gradual formation of the risk reduction factors catalog and thorough use of recommendations for choosing alternative sources of investment project finance in terms of NPV. The above approaches allow to make reasonable investment decisions in accordance with the existing criteria, such as NPV method, rate of return on investment, reasonable investor's expenses for keeping its economic potential.

The editor-in-charge of this article was Irina M. Vechkanova

The authorized translation by Irina M. Vechkanova

Please cite this article as: Khakhanaev U.S.-E. The Study into Factors Reducing Investment Project Financing Risks. Digest Finance, 2019, vol. 24, iss. 4, pp. 395-402. https://doi.org/10.24891/df.24.4.395

\section{Introduction}

Risks are inherent in any large investment project that absorbs substantial amounts of financing. The existing risk management practices primarily refer to insurance. Insurance helps not only rely upon professional expertise, but also releases financial resources, raises insurance funds, concurrently decreasing losses

\footnotetext{
"For the source article, please refer to: Хаханаев У.С.-Э. Исследование факторов снижения рисков финансирования инвестпроектов // Финансы и кредит. 2019. Т. 25. № 9. C. 2167-2178. URL: https://doi.org/10.24891/fc.25.9.2167
}

and uncertainty associated with investment projects [1]. Risks should be identified for each project, with the appropriate insurance strategy being defined. Investors should deal with the risk probability assessment, which underlies one of the risk insurance strategies, and outline possible risk management strategies. Choosing to finance a certain version of an investment program, the investor purchases the efficiency of its investments, which is declared by those initiating the investments [2]. Investment constituteb longterm capital expenditures for its subsequent 
increment. Like any business operations, investing goes hand in hand with risks ${ }^{1}$. Risk is a determining factor in project financing, since it is the risk that influences any changes in the feasibility of the project in terms of expenses, solvency and ability to repay dividends to shareholders [3].

Investment risk reflects the probability of financial losses and sources and factors that influence the type of risks. Diversification has served to mitigate risks for a long time. The significance of factors influencing the investment portfolio behavior stems from the allocation of risks and subsequent decrease in their adverse effect on the overall outcome of the project.

\section{Subject of Research}

The study primarily unfolds the analysis of factors reducing investment project financing risks. To accommodate for risk factors in the project performance evaluation, I consider any available information on methods that reduce financial risks, prevent risks, and how internal factors influence the level of risks as part of attempts to eliminate negative consequences and, therefore, adverse effects on the pace of economic development. The methodology for investment feasibility analysis seems even more important in terms of strategic security of the national economy [4]. Operating and investing activities are subject to different limits of financial proceeds from respective projects. Therefore, methodological guidelines for reducing investment risks through the catalog og investment project financing risks are reviewed with reference to groups of factors influencing socio-economic processes. What significantly mitigates the innovation risk are the thorough preparation of business planning milestones and forecast of socio-economic outcomes [5].

Project risks tests should necessarily be added to a set of investment analysis metrics [6]. Analyzing investment risks, investors should remember about distinctive features of a sectors, factors influencing the level of risk, and risk

\footnotetext{
${ }^{1}$ Garifullin A.F. [Finance of investment projects. How to Mitigate Risks]. Planovo-ekonomicheskii otdel $=$ Planning and Economics Department, 2013, no. 4. URL:

https://www.profiz.ru/peo/4_2013/snizhenei_riskov/ (In Russ.)
}

treatment, keeping focus on those factors that reduce investment risks. Successful business performance is indispensable without risk management [7].

\section{Objectives}

This study aims to investigate how groups of investment project financing factors influence the outcome of the projects. Based on empirical research, I address a new issue of investment project finance, that is, substantiation of the most cost-effective financial sources that boost cash flows. For example, payment to contractors and employees upon the acquisition, construction, reconstruction and preparation of non-current assets for operations; payments upon the acquisition and disposal of shares (interests), in other entities, other than short-term financial investment. New tasks help do so. For example, modeling the gradual preparation of an investment project risk catalog, which classifies risks, describes risk factors and their impact on the investment process. I should also mention efforts to determine factors reducing investment project financing risks.

\section{Materials and Methods}

To examine the formation of investment project financing risk factors, I refer to materials on investment projects, respective methods for comparing the efficiency of NPV discounting, economic potential of the investor, business, comparison method, compare and group risk factors. Justifying the most effective type of investment project financing that I choose for purposes of risk mitigation in the case of alternative investment projects, I suggest arranging the projects by priority of their respective criteria and tests. In my opinion, criteria and test should include methods based on discounted estimated and generally accepted methods, such as $N P V, I R R$ and $P I$, with the first one (NPV) being an absolute indicators, while the others (IRR and $P I)$ are relative.

\section{Discussions and Results}

Investment risk management is a comprehensive procedure, being, on the one hand, a part of the overall business management of a business, but, 
on the other hand, in certain circumstances investment risk management is a higher level practice in comparison with the general management [8]. Investment risk analysis should accommodate for the specifics of a sector, factors influencing the risk and risk mitigation measures. The analysis should also focus on factors reducing investment risks. To mitigate the high project exposure, the investor should find appropriate methods to do so.

Describing the investment risk in terms of possible losses in each group of risks, we should consider unpredictable scenarios arising from factors and shaping financial flows. The investment risk exposure is viewed as an undeniable factor influencing the investment project risks. A decrease in the investment risk has a positive impact on domestic investors' behavior, factors reducing investment risks and search for possible options to lower investment risks. That is, the outcome of investing activity depend on a variety of factors throughout phases of the project life cycle and, therefore, risk mitigation measures.

The existing methodology for investment project financing risk mitigation provides for scenario trees, being tested through public risk assessment. For example, the Novgorod Oblast (Russia). In such a case, all possible risk mitigation measures are considered $^{2}[9,10]$. As a result of the study, I offer my own methodology, which implies the formation and use of the investment project financing risk catalog and risk mitigation factors. I illustrate a sequence of catalog creation steps (my own scenario). Risk catalogs have not been presented in literature on risks yet as I view it here.

\section{Step 1. The Classification of Risk Types}

As part of Step 1, types of investment project financing risks, which depend on the external and internal environment, are examined and grouped. Moreover, I believe it is reasonable to introduce not only financial, but also indirect risks that can influence cash flows of investment projects.

\footnotetext{
${ }^{2}$ Atlasova N.G. [Risk management in project finance]. Obshchestvennye i ekonomicheskie nauki: materialy konferensii [Proc. Sci. Conf. Social and Economic Sciences]. Moscow, MtsNO Publ., 2017.

URL: https://nauchforum.ru/archive/MNF_social/1(41).pdf
}

\section{Step 2. Description of Risk Factors and Their Impact on Investment Process}

Each of the risk factors (external and internal) are described, referring to their effect on the investment project performance.

\section{Step 3. Outlining Action Plan to Determine Investment Project Financing Risk Factors}

Choosing what steps should be undertaken to reduce investment risks and a specific method to do so, public sentiment on companies should be taken into consideration, with key principles being respected.

1. An amount exceeding the equity should not be put at stake.

2. Consequences of the risks should be analyzed to decide on the risk reduction method.

3. Companies should assess the highest loss they may incur in case of an unfavorable scenario, compare it with capital expenditures and equity so as to prevent their bankruptcy.

4. The investment project risk exposure should be mitigated through the high liquidity of assets earmarked, thus allowing to sell them quickly and cut losses.

Revenue and variable expenses are crucial aspects that shape the feasibility of investment projects. In the case of alternative investment projects, companies should first choose a test and use it to arrange projects. Such tests may include methods which are based, first of all, on discounted estimates and, second, the generally accepted methods, such as NPV, IRR and PI. However, I should mention that $N P V$ is an absolute value, while IRR and $P I$ are relative.

NPV (net present value) has its own advantages, since it accommodates for the allocation of gains and losses from every investment opportunity. The method shows the difference between the current value of cash flows from projects and investment and current value of payments intended to secure investment or project financing, which are calculated at the fixed discount rate. 
The formula below is used to assess the latter indicator [11]:

$$
N P V=\sum_{k=j}^{n} \frac{C F_{k}}{(1+r)^{k}}-1 C .
$$

Here we have occasional NPV-based decisions on the investment project as follows.

If $N P V>0$, the project should be accepted. If $N P V<0$, the project should be declined. If $N P V=0$, the project generates neither gains nor losses.

IRR (Internal Rate of Return) shows the discount rate for zero $N P V$. The discount rate serves for analyzing the feasibility of investment planned. $I R R$ is indicative of the highest tolerable expenses on the project. It is virtually sensitivity to the bank interest rate. Thus, when the investment project is financed with a loan of a commercial bank and IRR hits the upper bound of the tolerable interest rate, the investment project is deemed unprofitable.

$I R R$ is associated with the cost of advanced capital (payment for the use of advanced financial resources injected into corporate performance $C C)$.

CC (cost of capital) represents some reasonable expenses the investor incurs to sustain its economic potential. As for the project, the following conditions shall be met. If $I R R>C C$, the project should be accepted. If $I R R<C C$, the project should be declined. If $I R R=C C$, the project generates neither gains nor losses.

$P I$ (Profitability Index) differs from NPV, since it is a relative value. Thus, it is more convenient to choose a project among alternative options that have more or less equal $N P V$ or the highest $N P V$ in case of portfolio investment.

The formula below is used to calculate PI [11]:

$$
P I=\sum_{k=1}^{n} \frac{C F_{k}}{(1+r)^{k}}: 1 C \text {. }
$$

$P I$ implies the following decision-making strategy. If $P I>1$, the project should be accepted. If $P I<1$, the project should be declined. If $P I=1$, the project generates neither gains nor losses.
Insurance is another strategy for risk mitigation. Following it, the company offloads its liability onto the insurance company. The following aspects should be considered to make this option more efficient:

1) assessing the probability of an event;

2) the extent of insurance coverage with the existing insurance rate;

3) comparative assessment of the insurance rate set for the case;

4) an amount of insurance payouts.

\section{Practice}

In Russia, insurance coverage usually applies to buildings, equipment, human resources. Investment project risk management methods often envisage provisions for unforeseen situations. In the Western countries, the coefficient usually accounts for 12 percent of total project value to hedge against such force majeure expenses. Trying to reduce investment risks, companies more often than not do as follows:

- making provisions and allowances;

- earmarking financial resources to write off bad debts;

- maintaining the adequate stock of production materials;

- forming the leveraged balanced of cash and highly marketable assets.

Investment risk mitigation methods require additional information, which may be obtained from third parties, for instance. Doing so, companies will clarify important aspects of the project, verify the information and decrease the probability of an ineffective decision. They will eventually justify their spending on additional information. Such information helps choose projects with a lower risk exposure. Table 1 presents the investment project financing risk catalog and factors reducing such risks.

\section{Conclusion}

I infer the following conclusions from the analysis. 
First, there are two investment risk management methods to enhance the security of projects. The first method is meant to avoid them at all. As part of the first method, companies analyze and exclude possible risk during decision-making. They may also reject some activities that put their financial stability at stake. More often than not they do as follows:

- refraining from substantial borrowings, thus avoiding financial risks;

- refraining from investing in non-marketable projects.

Simplicity and zero losses are what makes this strategy advantageous. However, the performance perishes if companies ignore very profitable projects due to high risks they are associated with.

The second option serves for reducing investment risks. This strategy comes up when companies conclude and implement contracts. Investment risk management methods work in the following manner:

- concluding insurance contracts;

- envisaging various securing options: collateral, guarantees, surety, forfeits that may even escalate into debtor's property forfeiture;
- coordinating a gradual approval of project payments;

- applying risk diversification methods.

Second, companies control managerial decisions by making a provision for unforeseen expenses and debt restructuring.

Employing the investment risk management mechanism, companies can measure the risk as the degree of their probable financial losses more accurately and completely. Investing is associated with a broad variety of risks, ways, methods and mechanisms for risk management.

Finally, factors that influence investing vary at the micro- and macrolevels. Risk management methods for financial investment portfolios, such as hedging, deposit portfolio diversification, provide for the temporary placement of resources. In this article, the economic substance, classification of financial risks and their practical implications are viewed through the proposed management tool - the investment project financing risk management catalog. IT makes some scientific and methodological contributions to the theory of risk and decision-making in the context of investment projects.

Table 1

Catalog of risks inherent in investment project financing and risk mitigation factors

\begin{tabular}{|c|c|c|}
\hline Types of risk & $\begin{array}{l}\text { Risk factors and description } \\
\text { of their implications for } \\
\text { investing }\end{array}$ & Factors and risk mitigation options \\
\hline \multicolumn{3}{|c|}{ 1. Risks associated with the policy of investors and entrepreneurs } \\
\hline Management risk & $\begin{array}{l}\text { Inconsistency of project } \\
\text { management with the existing } \\
\text { management style }\end{array}$ & \multirow{4}{*}{$\begin{array}{l}\text { Risk diversification. Risks are diversified if the focus is } \\
\text { dispersed among projects with unrelated results. Diversifying } \\
\text { risks, the person in charge should examine the correlation } \\
\text { with other strands of corporate operations. Investment risks } \\
\text { do decrease as a result of diversification, since the production } \\
\text { of goods and services is planned so to match the opposite } \\
\text { trend in demand. Investment risks can also be effectively } \\
\text { reduced if responsibilities of stakeholders are distributed by } \\
\text { transferring some risks to partners or appointing parties in } \\
\text { charge of project performance, who will appropriately and } \\
\text { competently analyze and control the risky line of business. } \\
\text { Such aspects are taken into consideration during financial } \\
\text { planning, being stipulated contractually }\end{array}$} \\
\hline $\begin{array}{l}\text { Conflict-of-goals } \\
\text { risk }\end{array}$ & $\begin{array}{l}\text { Conflict of expected project } \\
\text { goals and key principles of the } \\
\text { investor's policy }\end{array}$ & \\
\hline Project risk & $\begin{array}{l}\text { Conflict of expected project } \\
\text { results and business investment } \\
\text { policy }\end{array}$ & \\
\hline Strategic risk & $\begin{array}{l}\text { Neither entrepreneurs nor } \\
\text { investors can attain any long- } \\
\text { term results }\end{array}$ & \\
\hline
\end{tabular}




\begin{tabular}{|c|c|c|}
\hline \multicolumn{3}{|c|}{ 2. Technological Risks of Project } \\
\hline $\begin{array}{l}\text { Management and } \\
\text { control risk. } \\
\text { Practical risk. } \\
\text { Temporary risk }\end{array}$ & $\begin{array}{l}\text { No knowledge/skills to practice } \\
\text { project management principles. } \\
\text { Insufficient information and } \\
\text { explanations. } \\
\text { Negligence/insufficient } \\
\text { commitment to implementing } \\
\text { project results }\end{array}$ & $\begin{array}{l}\text { Multiple methods to prevent or decrease financial losses, i.e. } \\
\text { the normative method, insurance provisions, insurance against } \\
\text { the risk, insurance against the interest rate risk, hedging, } \\
\text { diversification. Posting risk management costs to the cost of } \\
\text { products to the extent permitted by laws. } \\
\text { Technical security standards for machines and devices, which } \\
\text { industrial enterprises must comply with. Enlisting priority risk }\end{array}$ \\
\hline Analytical risk & $\begin{array}{l}\text { Failure to gradually complete } \\
\text { the project, thus causing the } \\
\text { budget and capacities to outrun }\end{array}$ & $\begin{array}{l}\text { management measures, general principles for conducting such } \\
\text { measured at industrial enterprises and limiting contingency } \\
\text { losses. }\end{array}$ \\
\hline Result risk & $\begin{array}{l}\text { Failure to correctly use analysis } \\
\text { tools and comprehend the } \\
\text { outcome of the analysis } \\
\text { properly. } \\
\text { Failure to completely apply } \\
\text { the findings to respective } \\
\text { alternatives of the project }\end{array}$ & $\begin{array}{l}\text { Analyzing unforeseen expenditures. Risk management } \\
\text { measures. Budget adjustment. Risks should be classified and } \\
\text { identified for their timely assessment, forecasting negative } \\
\text { effects during innovative processes. } \\
\text { If additional expenses are to be incurred for the measures, } \\
\text { they should be commensurate with the effect they give with } \\
\text { respect to a specific risk. For instance, expenses to mitigate }\end{array}$ \\
\hline Methodological risk & $\begin{array}{l}\text { Unclear goals, purposes, } \\
\text { insufficient competencies }\end{array}$ & $\begin{array}{l}\text { the machine operation risk should induce less frequent idle } \\
\text { hours, breakdowns and higher productivity }\end{array}$ \\
\hline
\end{tabular}

\begin{tabular}{|c|c|c|}
\hline \multicolumn{3}{|c|}{ 3. Economic Risks } \\
\hline Expense risk & $\begin{array}{l}\text { Understating or } \\
\text { underestimating direct and } \\
\text { indirect costs (expenses on } \\
\text { third party advisers and idle } \\
\text { hours of project stakeholders) }\end{array}$ & $\begin{array}{l}\text { Discount rate. Production risk management measures, risks } \\
\text { associated with suppliers and customers. Risks may decrease } \\
\text { or increase the expected income. Managing risks, companies } \\
\text { can mitigate some of them by detecting possible risks, } \\
\text { determining possible remedies and estimating respective }\end{array}$ \\
\hline Income risk & $\begin{array}{l}\text { Mismatching (disparity) factual } \\
\text { expenses and anticipated } \\
\text { income - re-estimation } \\
\text { of income/savings }\end{array}$ & $\begin{array}{l}\text { costs. Analyzing expenditures for unplanned risk management } \\
\text { measures, undertaking risk mitigation actions requiring to } \\
\text { insure the project against undesired outcomes, diversify } \\
\text { investment and make provisions, etc. Formalizing the findings }\end{array}$ \\
\hline $\begin{array}{l}\text { Economic and } \\
\text { strategic risk }\end{array}$ & $\begin{array}{l}\text { Expected results of the project } \\
\text { conflict with the strategic } \\
\text { course of the investor and } \\
\text { entrepreneurs }\end{array}$ & $\begin{array}{l}\text { as a special program which should be approved by top } \\
\text { executives. Its implementation should be continuously } \\
\text { monitored in terms of expected risk management results. } \\
\text { If the effect is negative, companies should adjust the above } \\
\text { measures and program correspondingly. } \\
\text { In risk management, control implies checking the risk } \\
\text { management process. Control helps learn about the } \\
\text { completion of the risk management program, return on risk- } \\
\text { exposed investment, profit-to-risk ratio. Relying on the } \\
\text { findings, companies modify their financial programs, align } \\
\text { their financial operations and risk management. As part of } \\
\text { control, the risk management efficacy is monitored }\end{array}$ \\
\hline
\end{tabular}

\begin{tabular}{|c|c|c|}
\hline \multicolumn{3}{|c|}{ 4. Social Risks } \\
\hline Dominance risk & $\begin{array}{l}\text { The person who performs } \\
\text { decisions or project manager } \\
\text { are strongly exposed to the } \\
\text { unpredictability of project } \\
\text { results, which undermines } \\
\text { the trust in the project - } \\
\text { management mechanism }\end{array}$ & $\begin{array}{l}\text { A biased comprehension of risk by corporate management. } \\
\text { The more traditional the risk management policy, the lower } \\
\text { the probability of unfavorable consequences and the higher } \\
\text { the risk management costs. } \\
\text { Total costs incurred to manage the risk, including external } \\
\text { sources of compensations and deferred payments, are } \\
\text { calculated with discount methods, being indicative of the risk }\end{array}$ \\
\hline Cooperation risk & $\begin{array}{l}\text { Lockout as a prohibition of } \\
\text { stakeholders' strikes / difficulty } \\
\text { to accept something new }\end{array}$ & $\begin{array}{l}\text { management efficacy provided the comparative analysis } \\
\text { concerns equal downward movements or reimbursement } \\
\text { of corporate losses. As part of control, risk management }\end{array}$ \\
\hline $\begin{array}{l}\text { Concerted action } \\
\text { risk }\end{array}$ & $\begin{array}{l}\text { A lack of personal agreement } \\
\text { among project stakeholders }\end{array}$ & $\begin{array}{l}\text { measures are analyzed. Risk management actions as part } \\
\text { of corporate performance }\end{array}$ \\
\hline
\end{tabular}


Agreement risk in target groups
A lack of target groups' agreement on the project implementation, goals and results

\begin{abstract}
Actions to cushion the effect of risks, project progress control, actions to mitigate project risks and control the project performance. Project task forces' proposals on risk management measures.

Effective management of investing through methods to directly influence the project risk exposure so as to decrease it as much as possible, enhance the security and financial stability of an entity. Evaluating trends in the risk and return, comparing the findings with goals and their attainment and concluding on the economic feasibility of the measures. The preventive function of insurance implies the concurrent conclusion of an insurance contract and remittance of insurance premiums so as to secure the finance of risk management actions.

There are two types of managers in terms of attitude to the risk. The first type represents managers who absolutely ignore risks and make decisions with reference to the future returns only. In the best case scenario, the company may derive high income, thus increasing its market capitalization. However, if the situation is not that optimistic, the company will have substantial losses. The second type of managers feature those ones who prefer to refrain from a project and future income because they are afraid of risks. In this case, the company is protected from risks and possible losses, but will anyway have losses due to the loss of opportunity
\end{abstract}

Source: Authoring

\section{Acknowledgments}

The study was supported by the Russian Foundation for Basic Research (RFBR) as part of scientific project № $19-310-90024$.

\section{References}

1. Prokhorova M.V. [Measures to reduce project risks]. Molodoi uchenyi = Young Scientist, 2019, no. 26, pp. 371-373. URL: https://moluch.ru/archive/264/61280/ (In Russ.)

2. Akinfiev V.K., Korgin N.A. [Organizational methods to reduce the risk of investment decisions]. Problemy upravleniya $=$ Problems of Management, 2011, no. 1, pp. 40-46.

URL: https://cyberleninka.ru/article/n/organizatsionnye-metody-snizheniya-riska-investitsionnyhresheniy (In Russ.)

3. Kazanskii A.V. [Risks of project financing and methods of their overcoming in Russian projects]. Problemy sovremennoi ekonomiki = Problems of Modern Economics, 2015, no. 1, pp. 139-143. URL: https://cyberleninka.ru/article/n/riski-proektnogo-finansirovaniya-i-metody-ih-preodoleniyav-rossiyskih-proektah (In Russ.)

4. Vyakina I.V., Aleksandrov G.A. [On the need to develop a methodology for evaluation of investment performance]. Rossiiskoe predprinimatel'stvo = Russian Journal of Entrepreneurship, 2018, vol. 19, no. 1, pp. 195-206. URL: https://cyberleninka.ru/article/n/o-neobhodimostirazvitiya-metodologii-otsenki-effektivnosti-investitsiy (In Russ.)

5. Fomin P.B. [Risks of financing of the innovative project and business plan as factor of decrease in innovative risk]. Transportnoe delo Rossii = Transport Business of Russia, 2011, no. 11, pp. 151-153. URL: https://cyberleninka.ru/article/n/riski-finansirovaniya-innovatsionnogoproekta-i-biznes-plan-kak-faktor-snizheniya-innovatsionnogo-riska (In Russ.) 
6. Bakeeva I.R., Kozlova A.A. [Risk management in the implementation of investment projects]. Vestnik akademii znanii = Bulletin of Academy of Knowledge, 2018, no. 3, pp. 39-43. (In Russ.)

7. Kovalev P.P. [Insurance of risks when implementing an investment project]. Ekonomika: vchera, segodnya, zavtra = Economics: Yesterday, Today, Tomorrow, 2018, vol. 8, no. 2A, pp. 47-55. URL: http://www.publishing-vak.ru/file/archive-economy-2018-2/5-kovalev-petr.pdf (In Russ.)

8. Tkhakushinov E.K. [Features of management of investment risk: Subject and object approach]. Mezhdunarodnyi zhurnal prikladnykh i fundamental'nykh issledovanii = International Journal of Applied and Fundamental Research, 2015, no. 8-2, pp. 343-346. URL: https://applied-research.ru/ru/article/view?id=7096 (In Russ.)

9. Yalmaev R.A., Eskiev M.A., Chazhaev M.I. [Risk management as a necessary condition for investment project financing]. Molodoi uchenyi = Young Scientist, 2015, no. 14, pp. 328. URL: https://moluch.ru/archive/94/21219/ (In Russ.)

10. Kleimenova A.V. [Classification of risks in project finance]. Ekonomika i sovremennyi menedzhment: teoriya i praktika = Economics and Modern Management: Theory and Practice, 2014, no. 37, pp. 144-156. (In Russ.)

11. Kovalev V.V. Finansovyi analiz: metody i protsedury [Financial analysis: Methods and procedures]. Moscow, Finansy i statistika Publ., 2001, 559 p.

\section{Conflict-of-interest notification}

I, the author of this article, bindingly and explicitly declare of the partial and total lack of actual or potential conflict of interest with any other third party whatsoever, which may arise as a result of the publication of this article. This statement relates to the study, data collection and interpretation, writing and preparation of the article, and the decision to submit the manuscript for publication. 